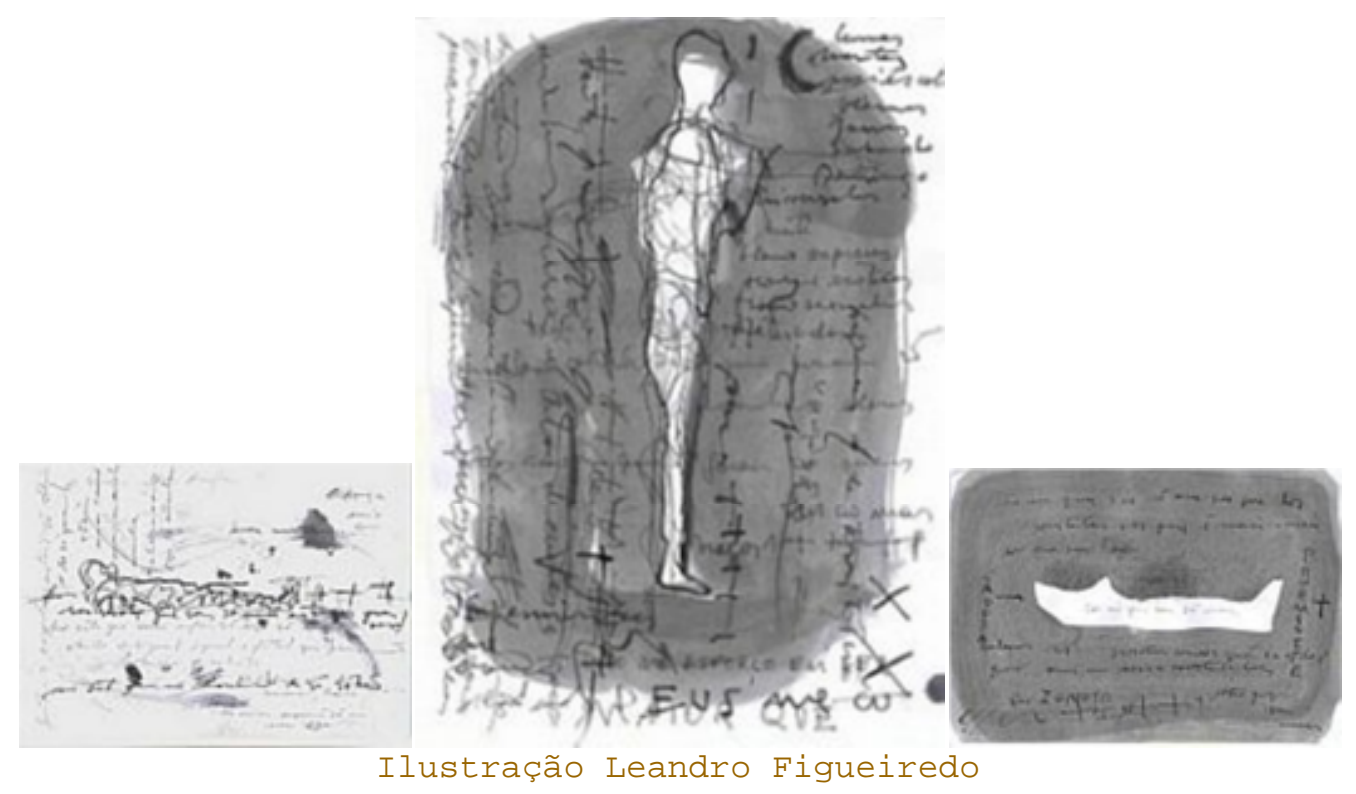

\title{
O condensador de luz
}

\section{Rynaldo Papoy}

Rynaldo Papoy, escritor, músico, ator, diretor. Publicou Suicídio Espiritual, poemas (1993) e O Deserto, teatro (2003). Está publicando seu primeiro romance de ficção científica, Alpha Centauri.

O professor de física da USP Godofredo Quintella acreditava que para viajar no tempo seria preciso sair deste Universo e caminhar num "anti-Universo" ou o "verso do Universo", como se uma pessoa subisse num prédio pelas paredes externas.

Professor Godofredo não gostava que chamassem esse "antiUniverso" de "Universo paralelo". Pois acreditava não haver nada ali.

Como atingir esse anti-Universo?

Por cinquenta e sete anos refletiu sobre isto. Até que numa manhã de inverno, fazendo a barba, chegou à conclusão:

- Viajando acima da velocidade da luz.

A luz viaja a $300 \mathrm{mil} \mathrm{km} / \mathrm{s}$ porque encontra uma resistência. Essa resistência é a própria parede da existência do Universo. 
Essa parede poderia ser rompida, ele acreditava, concentrandose a luz num ponto e a fazendo explodir.

Muita gente havia teorizado e pesquisado sobre coisas semelhantes. Como Stephen Hawking. E ele estava certo que se entrasse numa máquina destas, seria pulverizado e não veria coisa nenhuma.

Aos 98 anos, acreditando que não tinha nada a perder, construiu o seu Condensador de Luz e se sentou na frente dele.

Bastariam seis segundos de condensação. A luz o atravessaria como um laser e seria absorvida por um dispersador que a enviaria ao espaço.

Ele apertou o botão e liberou a luz.

Sua teoria estava quase certa. Ele, de fato, saiu do Universo mas não encontrou um anti-Universo. Encontrou uma espécie de Universo paralelo primitivo e em suspensão temporal, onde um Big Bang eterno, formado por toda luz de todos os Universos que ali eram jogadas por seus buracos negros e se concentravam eternamente num único ponto que se expandia, formando novos e infinitos Universos.

Nosso Universo, soube Professor Godofredo, era apenas uma centelha entre infinitas explosões que ocorriam num lugar que nunca teve começo nem terá fim, pois ali não existia o tempo.

Professor Godofredo chorou, suspenso no vácuo. Pois havia descoberto o segredo da Existência mas não poderia contar a ninguém. 